\title{
The Effects of Welfare State Universalism on Migrant Integration
}

\author{
Anthony Kevins and Kees van Kersbergen
}

Published at Policy \& Politics: https://doi.org/10.1332/030557318X15407315707251

\begin{abstract}
This paper investigates how and why welfare state universalism can shape the integration of migrants into the national community. Universalism is broadly regarded as central to the integrative and solidarity-building potential of welfare states, but we argue that the traditional approach to understanding the concept is fraught with inconsistencies. Rather than comparing welfare states using the classical universalist-selectivist dichotomy, we suggest that they should be thought of as embodying various 'packages' of universalist traits - all of which are unified by their connection to a core, self-sustaining logic of solidarity. A comparison of Canadian and Danish universalism allows us to draw out how (indiscriminate/selectivist) 'community perks' traits and (inclusive/exclusive) 'community scope' ones may interact in unexpected ways. This, in turn, helps us better understand how and why 'classically universalist' Denmark is facing threats to solidarity and migrant integration that are much more intense than those found in 'classically selectivist' Canada.
\end{abstract}

Key words: immigration, welfare benefits, statecraft, Canada, Denmark 
Social policy has long mattered for integration. Since its creation, the welfare state has been an important tool of territorial and social integration, connecting individuals of disparate regional, linguistic, religious, and class groups and fostering solidarity among them (e.g. van Kersbergen, 2000; Ferrera, 2005; Béland and Lecours, 2007). As Banting (1995, 270) has argued, 'national social programs create a network of intimate relations between citizens and the central government throughout the country, helping to define the boundaries of the national political community and enhancing the legitimacy of the state'. Social policy has thus been a tool of statecraft, pushing forward integration on the basis of territorial bonds while at the same time diffusing inter-class tensions.

Universalism, with its focus on broad solidarity and access to welfare state provisions, is a central part of this story. Yet there are reasons to ask whether universalism, as classically understood, can continue to play its role as a tool of statecraft and social integration in the face of increasing migration.

The challenge of immigration to universalism has been articulated as the idea that 'the feeling of community and shared risk will crumble when strangers settle in the country' (Grødem, 2016, np.). Although broad support for the universal welfare state clearly persists, all of the Nordic, universalist countries now have strong anti-immigrant parties that have evolved into welfare-chauvinist parties i.e., parties that promote a generous welfare state for the natives but restricted access for migrants (e.g. Schumacher and van Kersbergen, 2016). Even so, Denmark stands out among the Nordic states, as its public and political discourse has especially strong and widespread anti-immigrant propensities (e.g. Agius, 2017). Confronted with a rapidly growing number of non-Western migrants, Danish politicians from the centre-left rightwards have been increasingly pre-occupied by what they term the 'parallel societies' found in 'immigrant ghettos.' These debates culminated in the 2018 introduction of the so-called 'ghetto package' of legislation, which introduced a series of measures intended to eliminate the 'ghettos' and inculcate Danish values, in particular among immigrant children. We argue that Danish-style welfare state universalism is an important factor lying behind such concerns. 
Even though a large body of work highlights the interplay between immigration, integration, and welfare state policies (e.g. Koopmans, 2010; Soroka et al., 2016), the importance of universalism for migrant integration has been relatively under studied. We therefore set out to explore the meaning and significance of universalism vis-à-vis migrant integration into the national community. First and foremost, we argue that the conceptual muddiness surrounding 'universalism', both as a concept and as a characteristic of certain welfare states, must be clarified if we want to unpack the relationship between universalism and the social integration of migrants. We suggest that this can be accomplished by thinking of universalism not as a classical concept, defined by a simple universalist/selectivist dichotomy, but rather as a family-resemblance one (Collier and Mahon, 1993; Goertz, 2005; Ferrera, 2016). This implies that the conceptual attributes that we consider analytically important to encapsulate universalism may typify a number of cases well, but no single case perfectly. From this perspective, insofar as welfare states share certain core attributes of universalism, we should identify them as belonging to the same, broader family of universal welfare states.

We then proceed to tease out two such attributes and discuss their importance via a comparison of two dissimilar cases, Canada and Denmark, where universalism has nonetheless had a shared importance as a tool of statecraft. We argue that while the Danish welfare state, with its extensive system of generous social programmes, fulfills the classical definition of universalism, the notably stingier Canadian welfare state highlights the relevance of another important aspect of universalism: community boundaries. Anticipating our terminology below, we suggest that universalism's core characteristic (or internal logic) is a self-reinforcing, virtuous circle of solidarity. Crucially, however, we argue that the playing out of that feedback loop over time will be shaped by the mix of universalist traits present in a given country, with important implications for migrant-native relations.

As this article suggests, Denmark's universalism centres around an extensive set of indiscriminate community perks - but for a relatively exclusive community - while Canada's is more focused on 
maintaining a broad conception of community scope - but with limited and more selective community perks. One consequence of this contrast is a far more frictionless incorporation of newcomers into the Canadian universalist community than into the Danish one (e.g. Koning, 2013; Bay et al, 2013). This challenges the common wisdom in the welfare state literature on universalism: that the universalism of social democratic welfare states is the gold standard when it comes to integrative potential. Against this position, we argue that differences across 'packages' of universalist traits can have counterintuitive implications for inclusiveness vis-à-vis migrants. By reinforcing the (perceived and/or real) importance of community boundaries, extensive indiscriminate community perks may pose a challenge to the inclusion of migrants within the existing community. In such cases, universalism's self-reinforcing logic of solidarity may, within a context of increased immigration, instead reinforce welfare chauvinism - with generous perks to be maintained, but only within an increasingly closed community.

The paper is structured as follows. We begin by rethinking the central concept of universalism and argue that the either/or opposition between universalism and selectivism (or residualism) that is prominent in the literature is fraught with inconsistencies. We then explain why, from an institutionalist perspective, universalism should matter for the incorporation of migrants into the existing community, laying out traditional arguments and interpreting them in light of our conceptualisation. Next, we elaborate the logic of the case selection and present our analysis of the Canadian and Danish cases. In the conclusion, we lay out the analytical advantage of our conceptual approach and draw out further comparative findings. In doing so, we highlight how taking into account the different 'packages' of universalism helps us to better understand why the relationship between universalism and migrant integration is more strenuous in Denmark than in Canada. 


\section{Universalism as a Family-Resemblance Concept}

Universalism has been a notoriously slippery concept in the social policy literature, which has led some researchers to discuss 'varieties of universalism' (e.g. Stefánsson et al., 2012). However, there is consensus regarding the core primitive notion (Lukes, 2005, 30) lying behind discussions of universalism. 'At a general level', write Carey and Crammond (2017, 303), 'universalism seeks to apply the same standards to all individuals... by not differentiating between groups, different standards are not created for how different groups are dealt with. That is, intentional abstraction is made from the pluralism of society in order to create "fairness"". And according to Anttonen et al. $(2012,4)$, the least disputed criterion for universalism is the idea of access for all citizens or residents to a particular benefit. Similarly, Stefánsson et al. $(2012,46)$ write that a policy is universal 'if it applies equally to everyone of a particular kind (for example, all citizens) regardless of whatever differences might be found between subgroups and individuals belonging to that group' [emphasis added]. Yet, this reference to a particular kind of person obscures a central issue with existing definitions of universalism: who gets to be included in the universe of universalism?

At the same time, within the literature on universalism, some social policies that explicitly produce differences in entitlements among citizens are nevertheless considered to be universal, while others that do the very same thing are not. Consider, for example, the contrast between child allowances and social assistance. Neither applies equally to everyone: the former only target families with children on the basis of (presumed) need, excluding everybody else, while the latter only targets the poor. Yet child allowances are considered a standard universalist benefit, while social assistance is not.

We propose that these sorts of conceptual issues can be addressed by acknowledging that universalism is a family resemblance concept (see Collier and Mahon, 1993). The welfare state literature commonly treats universalism as a classical concept, dichotomously contrasting 
universalism and selectivism/residualism in social policy (e.g., Van Lancker and Van Mechelen, 2015). We suggest, by contrast, that welfare states should rather be thought of as exhibiting varying subsets of key universalist traits, all of which are tied to a core logic. These traits include a variety of features - our case studies, for instance, highlight a shared commitment to egalitarianism, a link to national identity, and a focus on inter-group and inter-territorial solidarity - unified by their connection to a self-sustaining logic of solidarity (see Korpi and Palme, 1998; Rothstein, 1998). Yet, as the combination of universalist attributes present will vary from case to case, so too may the relationship between the core concept and various outcomes of interest.

This article focuses on what we argue are two key, clearly distinguishable traits: 'community perks' and 'community scope'. Previous work has tended to focus on generous, indiscriminate community perks as the marker of universalism, viewing them as central to the fomentation of self-reinforcing solidarity. We argue, however, that an inclusive community scope can fulfil a similar function - and that the existing mix of perks and scope has potential implications for migrant integration into the universalist community. Elaborating on these two traits thus allows us to draw out the tensions inherent in previous classical conceptualisations of universalism, while also permitting us to better understand recent trends toward welfare chauvinism - including in countries classically designated 'universalist' (e.g. Bay et al., 2013).

Turning first to community perks, we note that states differ dramatically in the range of benefits (whether in cash transfers or services) that they make available to the average citizen/resident: social programmes may be narrowly targeted (i.e. selective) or widely accessible (i.e. indiscriminate) for community members. The sum total of these programmes will be a set of community perks that are more or less selective (as per the traditional conceptualisation of universalism). Yet, if we reflect on the notion of community scope, we note that the group of individuals that is eligible to receive any given perk will at the same time be more or less extensive, depending on the country and the benefit. 
To illustrate the added value of thinking in these terms, let us focus momentarily on a single programme: healthcare. On the one hand, access to government healthcare within a state might be available to all community members (i.e. an indiscriminate community perk) or it might only be available to those of them who are unemployed (i.e. a selective community perk). In either instance, however, the 'community' could be relatively inclusive - for example, with benefits available to all unemployed residents, or to all persons passing through the country - or it could be relatively exclusive - for example, excluding asylum seekers, residents who have yet to meet lengthy stay requirements, migrants without papers, etc. (see, for example, Kevins, 2017). Universalism might thus entail relatively indiscriminate community perks, relatively inclusive community scope, or both at the same time.

Understanding universalism as a family resemblance concept has important implications for how we think about its application to actually-existing welfare states. As the next section demonstrates, this re-categorisation forces us to rethink standard arguments about the effects of universalism on migrant integration into the national community.

\section{Universalism as a Tool of Statecraft}

We begin from the position that universalism can have important implications for migrants, in particular with regard to their inclusion within the existing community. The basic argument here is that politicians can and do use social policy to generate and reinforce allegiances to the state and a sense of political community among the citizenry (see, for example, Banting, 1995; McEwen, 2005; Béland and Lecours, 2007). Indeed, Ferrera $(2005,45)$ conceptualises welfare state development as the institutionalisation of solidarity - situated within the process of territorial system-building - that tied individual life chances to the state. Universalism, with its focus on delivering benefits to citizens 
qua citizens (rather than, for example, by virtue of having made adequate contributions to a specific occupational scheme) is particularly well suited to serve as a tool of statecraft. On the one hand, the constellation of available benefits shores up the link between citizens and the state, while on the other, the scope of benefit access serves to reinforce community boundaries (see Banting, 1995: 270).

Indeed, many of the politicians who helped construct the welfare state seem to have made this connection explicitly: reflecting Marshall's (1950) conception of social citizenship rights and their potential to generate solidarity, architects of social programmes frequently used the language of universalism and pointed to social integration as a central goal of these projects (e.g. Christiansen and Petersen, 2001, 183). While immigrant groups were typically not the originally intended target of that integration, there are good reasons to believe that these mechanisms may matter nonetheless, and that welfare states will shape the integration of newcomers and ethnic minorities into society (e.g. Freeman, 2004). Key here are the linkages among citizens (both as individuals and collectivities) and between citizens and the state (see Lieberman, 2005, 57) - which are arguably more likely to develop vis-à-vis immigrants within generous welfare states (c.f. Crepaz and Damron, 2008; Koopmans, 2010).

To put existing research in our terms above, this standard argument suggests that the more extensive and indiscriminate the community perks, the better the link between (1) newcomers and native-born citizens and (2) newcomers and the state. Selectivism in community perks, by contrast, is typically linked with fracturing and antagonism. According to this literature, greater selectivism entails risks that are intricately tied to the self-reinforcing logic of universalism (e.g. Rothstein, 1998; Jacques and Noël, 2018). Yet how should we understand these critiques if, as we suggest above, universalism cannot simply be defined in opposition to selectivism? Focusing on migrant-related consequences highlights two potentially critical issues. 
First, the standard pro-universalist argument suggests that, while selectivism carves the population into various, often at odds, groups (e.g. benefit recipients versus taxpayers), universalism sends the message that the welfare state exists for all, regardless of class, place of origin, or other differences. This creates a broad, in-built pro-welfare state constituency (e.g. Korpi and Palme, 1998). Universalism thus forces those who favour more selective policies and services into a politically disadvantaged and defensive position, as they would somehow need to argue for the unequal treatment of citizens (Rothstein, 1998).

Once we consider the importance of community scope, however, this relationship becomes more complex. More selective benefits, such as those with income-based eligibility requirements, treat members of the community unequally; but precisely because of this selectiveness, would-be reformers, as well as the public more broadly, may be less inclined to restrict community scope. On the other side of the traditional selectivist/universalist distinction, by contrast, an indiscriminate benefit may actually be more vulnerable to arguments in favour of the unequal treatment of individuals, since it does not discern between 'deserving' and 'underserving' recipients (e.g. van Oorschot, 2000; Jensen and Petersen, 2017). This is especially the case when an increase in the saliency of the migrant-native cleavage threatens to upset a previous equilibrium.

A second standard argument posits that universalist welfare states are much less vulnerable than other systems to asserted violations of the 'fair share' principle (e.g. Rothstein, 1998; Larsen, 2008). Selectivism, by contrast, undermines this positive attribute by making it easier to stoke fears of fraud and other abuse. Declared misuse of provisions and fraud are more plausible when needs and means are tested than when benefits and services are provided more indiscriminately. This minimizes concerns that any particular group could be guilty of misusing the system - with immigrants a particularly likely target of such claims (e.g. Soroka et al., 2017). 
Taking into account community scope, however, once again suggests a far murkier distinction. On the one hand, asserted violations of the fair share principle likely rely more on the type of eligibility criteria (especially vis-à-vis the strictness of the underlying requirement) than the existence of a criterion in and of itself. Yet a universal childcare allowance, for example, may be criticized not only for fraudulent claims, but also for overreliance by immigrants hoping to 'cash in' by having more children. Importantly, this latter sort of criticism is often articulated in assertions that newly admitted outsiders - not (yet) adapted to community standards - are taking advantage of generous community perks (e.g. Favell, 2003).

To be clear, none of this is to suggest that the distinction between indiscriminate and selective benefits is unimportant. Rather, we argue that in order to properly understand universalism's effects, we must consider which key traits are present and to what degree they can effectively reinforce the positive feedback loop between social policies, political support, and a sense of community (e.g. Laenen, 2018). Insofar as welfare states facilitate the incorporation of newcomers and are integral to certain shared identities (e.g. Johnston et al., 2010), within a context of rising immigration, the playing out of this self-reinforcing logic is likely to have increasingly important consequences over time.

The argument here, then, is that some packages of universalist traits are potentially more fragile than others. In particular, we suggest that extensive, indiscriminate community perks may go hand-in-hand with a push toward welfare chauvinism (i.e. shrinking community scope), as more generous universalist benefits may stoke increased fears about the motivation and disposition of newcomers in the process undercutting the ability of the welfare state to generate links of solidarity between newcomers and native-born citizens. Paradoxically, then, indiscriminate universalist welfare states may have a harder time bringing migrants into the existing community than more selectivist variants. 


\section{Case Selection and Empirical Strategy}

To explore this potential relationship, we home in on two cases that are generally considered contrasting welfare state regimes (Esping-Andersen, 1990; van Kersbergen and Vis, 2014): Denmark, a social democratic welfare regime, where the community perks are relatively indiscriminate and extensive; and Canada, a liberal welfare regime where they are, on average, more selective and limited.

Despite these differences, both countries have a well-documented history of using universalist social policy as an instrument of statecraft, with universalism tied to both Danish and Canadian identities. Indeed, this is what gives our two-country comparison its force: the cases embody distinct incarnations of universalism. On the one hand, there is the Danish commitment to cross-class solidarity through a generous welfare state, arguably made possible by an almost 'tribal' attitude premised on ethnic homogeneity (Campbell and Hall, 2010; Jespersen, 2011, 5ff). On the other, the comparatively meagre Canadian welfare state has been used to construct a shared identity across geographically dispersed and ethnically differentiated groups (Brodie, 2002a). Thus, while universalism has served as an instrument of statecraft in the two countries, the Danish variant has an extensive set of community perks (but for a relatively exclusive community), while the Canadian one has been more open to incorporating newcomers into the community (but with limited and more selective community perks).

In discussing our two cases, we begin by providing some historical background to highlight the role of universalism in these countries' welfare state institutions. We then lay out a brief overview of the Canadian and Danish welfare states, as well as their respective integration outcomes vis-à-vis migrants. In doing so, we aim to draw out (1) the interplay between the two universalist traits under 
discussion and (2) their consequences on universalism's integrative, solidarity-reinforcing capacity in the face of increasing immigration.

\section{Canada: Circumscribed Universalism in a Settler Society}

Given the lack of a shared foundational myth or a pre-Confederation collective identity, the state played a key role in developing a Canadian identity in the $20^{\text {th }}$ century (Brodie, 2002b, 163). Up to the First World War, nation-building was primarily a question of infrastructure creation, linking citizens living on Canadian soil; but in the wake of the Second World War, Canadian identity was yoked to social policy, with the move toward the 'social Canadian' (Brodie, 2002a, 384). Indeed, already in 1945, the then Liberal government was arguing that a social security programme had the potential to 'strengthen true Canadian unity... [and provide] a vital contribution to the development of our concept of Canadian citizenship and to the forging of lasting bonds of Canadian unity' (Canada, 1945, 28). While in the short-term, federal governments were in fact hesitant to enact such policies (see Finkel, 1993), over the next decades (in particular the 1960s) they pushed this project forward substantially (though see also Siltanen, 2002).

Welfare state development was thus a key component of the development of a collective identity (Banting, 1995; McEwen, 2005), a process that was further expanded with the rise of the Québec sovereigntist movement (from the 1960s onward) and the competitive state building that entailed (Béland and Lecours, 2006). The statecraft goals of this initial project were seen to extend relatively seamlessly to new immigrants - although class conflict and labour unions played a role in welfare state development, the resultant system was designed at least partially to foster a shared identity among earlier immigrant waves. 
Importantly, universal appeals were a central facet of the Canadian welfare state, notwithstanding its liberal design. Allusions to universalism fully transcended the universalist/selectivist dichotomy common in the literature. On the one hand, several rather indiscriminate community perks were 'accurately' described as universalist: Medicare (1966), which has played a role similar to the UK's National Health Service vis-à-vis national identity; Old Age Security (1951), the basic pension plan that provides a relatively modest baseline income; and the now-defunct Family Allowance programme (1944). Yet universal language was also employed to describe contribution-based insurance programmes, most notably Employment Insurance and the Canada Pension Plan, due to their - in principle - availability to all. Only fully selectivist means-tested benefits were held up in contrast to universalism (Brodie, 2002a, 384).

The contours of the Canadian welfare state have been stable in the decades following its creation, despite substantial cost-control measures by the federal government (Béland et al., 2014). The few prototypical universalist programmes that were introduced in the post-War period persist in relatively unaltered form. Medicare has been the most resilient (though government programmes only cover about $70 \%$ of total health expenditure (OECD, 2018a)); Old Age Security, in turn, has only been clawed back from the highest earners (Béland et al., 2014). Even the universalist Family Allowance, eliminated in 1993, made a temporary return in 2006 with the Universal Child Care Benefit for families with children under 6 years old, before being cancelled by the current Liberal government (which replaced the programme with the means-tested Canada Child Benefit in 2016). The only noteworthy expansion of Canadian community perks occurred at the sub-state level, with the 1997 creation of a universal childcare system in Québec, which remains to this day the country's sole public programme.

This limited set of indiscriminate community perks sits alongside a relatively open conception of community scope. The extent to which foreign-born residents are eligible to benefit from these 
programmes varies by type of migrant. However, for the largest group - permanent immigrants most restrictions on welfare state access are de facto rather than de jure. Limitations in access reflect residency requirements for Old Age Security and Medicare, as well as contribution requirements for Employment Insurance and the Canada Pension Plan; the major exception here is sponsored immigrants, for whom sponsors must assume much of the responsibility for benefit provision (for a summary, see Koning and Banting, 2013, 594). Welfare state access for temporary foreign workers and asylum seekers, by contrast, is markedly more restricted. These groups face direct restrictions on a wide array of benefits, both indiscriminate and selective (Koning and Banting, 2013). But because of the large accumulated number of permanent immigrants, these limitations affect only a relatively small proportion of the total foreign-born population.

It is nonetheless with these (typically less-skilled) groups that it seems easiest to place migrant groups outside the scope of the Canadian universalist community. For example, a 2014 reform allowing provinces to restrict asylum seekers' access to social assistance was defended by the then Immigration Minister's press secretary precisely in this way: 'Canada has the most fair and generous immigration system in the world. However, Canadians have no tolerance for those who abuse our generosity and who take unfair advantage of our generosity' (Curry, 2014). Similarly, in the 2015 election campaign, (the then Prime Minister) Stephen Harper declared that 'we do not offer [bogus refugee claimants] a better health-care plan than the ordinary Canadian can receive. I think that's something that new and old stock Canadians can agree with' (CBC News, 2015).

At a general level, however, such exclusionary turns are comparatively uncommon: Canadians are relatively unlikely to believe that country ancestry or place of birth impact whether or not one can be a "True Canadian", and xenophobia is generally considered low by international standards (e.g. Ariely, 2012; Wright, 2011). Of course, this does not suggest that the country is somehow 'postracial': immigrants are just as likely to say they are subject to discrimination as in the average OECD 
country (OECD, 2015), and immigrant sense of belonging lags particularly behind in Québec (Banting and Soroka, 2012). The major hitch, however, is that the liberal nature of the Canadian welfare state, with its relatively limited community perks and below-average social expenditure (see Noël, 2018), leads inequality and poverty to affect immigrants to Canada at markedly higher rates than in most other OECD countries: the in-work poverty rate among immigrant households, for example, is almost $30 \%$ - worse than in the US and second only to Greece (OECD, 2015). Yet the 'virtue' of the Canadian system is that such problems afflict the foreign-born population at levels that are only modestly worse than those of the native-born population (OECD, 2015).

\section{Denmark: The 'People's Community'}

Denmark has a prototypical 'universalist', Social Democratic welfare state (Esping-Andersen, 1990; Anttonen et al., 2012). Although the 'bourgeois' parties developed the main inclusive features of the welfare state via social laws quite early on, the modern Danish welfare state has its roots in a 1933 reform. This broad social and political covenant between the Social Democrats, Liberals, and the Social Liberal Party came about in response to the Great Depression. These changes implied increasingly inclusive coverage and an end to the Poor Law-like treatment of benefit recipients. In short, it led to the firm establishment of social citizenship as the key building block of the welfare state (Christensen, 2004). The Social Democrats then started to explicitly promote national integration of the 'people's community' (Folkefaellesskab) through the gradual extension of social rights (Christiansen and Petersen, 2001; Edling et al., 2014). This establishment of social citizenship and its gradual expansion after the Second World War, created the political institution of the universal welfare state (Rothstein, 1998). 
The key concerns here were class-related, but a territorial dimension also lurked in the background. On the one hand, there is the centre-periphery cleavage between Copenhagen and the rest of Denmark; this has its historical roots in the loss of the duchies of Schleswig and Holstein to Germany in 1864 and the subsequent desire to develop 'lost agrarian lands' and reorient them away from Hamburg and toward Copenhagen (Østergård, 1992). On the other, there is the split between more and less prosperous areas. The division, typically drawn very broadly, contrasts the comparatively well-off core of Denmark with the so-called 'rotten banana' (rådne banan) - the banana-shaped area that stretches from the western coast of Jutland to Møn, covering the most socially- and economically-challenged regions.

In seeking to address these integration challenges, successive Danish governments have developed and reinforced a welfare state that fuses 'universalism with generosity and... [the] comprehensive socialization of risks' (Esping-Andersen, 1999, 79). The list of available indiscriminate community perks is too extensive to include here, but ranges from predictable yet essential services, such as healthcare, to more singular programmes such as Statens Uddannelsesstøtte, a set of generous state educational support grants available to university and older high-school students. The Danish unemployment insurance system is the major non-universalist exception, as it continues to follow the 'Ghent'-logic of union-managed insurance (with benefits dependent on contributions); however, since 1907 the state has assumed the responsibility to provide supplementary financing in case of need, turning it into a quasi-universalist scheme. The indiscriminate public pension, in turn, is part of a three-tier system where occupational and private pensions top up the universal 'people's pension'.

As in Canada, the set of available community perks has been relatively stable over recent decades in Denmark, despite numerous reforms at the margins. The real value of various benefits (e.g. social assistance, pensions) have decreased through a failure to fully index them; other programmes have 
been directly cut (e.g. family benefits, social assistance for the young) or had their access restricted (e.g. minimum income schemes) (Kvist and Greve, 2011). Unemployment benefits, in turn, are now more contribution dependent, shorter in duration, more demanding vis-à-vis requalification, and less generous and inclusive (Goul Andersen, 2012, 180). But even in the face of these changes, Denmark's social expenditure (28.7\% of GDP) remains not only well above the OECD average (21\%), but also far higher than that of Canada (17.2\%) - and universalism, as classically understood, remains the cornerstone of the Danish welfare state (Béland et al., 2014; OECD, 2018b - figures from 2016).

In light of Denmark's extensive set of indiscriminate community perks, equality of outcome, equality of opportunity, and social mobility have become defining characteristics of the Danish selfimage. In principle, the welfare state is seen not as an economic burden, but as an extensive social and political accomplishment to cherish and be proud of. Yet, as Grødem (2016, np.) argues, this attitude exists alongside a pressing concern that 'the feeling of community and shared risk will crumble when strangers settle in the country'. The result has been an increasingly prominent turn toward welfare chauvinism - arguably the prototypical manifestation of an exclusive community scope - with cuts to immigrant access occurring alongside the expansion of programmes aimed at the middle class (Goul Andersen, 2012; Bay et al., 2013). Related reforms have taken various forms, with the most notable being the 2002 replacement of immigrant access to social assistance with access to a markedly less generous 'start assistance' benefit for newcomers with less than seven years of residence (Goul Andersen, 2007).

This exclusionary turn is clear both among Danish parties and the public more broadly, which has greeted increased immigration with scepticism and concern about the development of 'parallel societies'. The recent European refugee crisis has been a particular flashpoint, but these preoccupations date back almost to the beginning of the modern immigration period in the $1980 \mathrm{~s}$ 
(e.g. Favell, 2003; Green-Pedersen and Krogstrup, 2008). Danes tend to fare poorly on xenophobia indices (e.g. Ariely, 2012) and welfare chauvinism is relatively popular, with about 40 per cent of the population at least partly supporting differential treatment of immigrants in 2008 (Bay et al., 2013). Finally, the comparatively generous Danish welfare state offers one last marked contrast with the Canadian one: while inequality and poverty are less serious problems for Danish immigrant population than their Canadian equivalents, the difference between foreign- and native-born Danes tends to be much greater. Taking back up the example of in-work relative poverty, for instance, one notes that the rate for Danish individuals living in an immigrant household (16\%) is almost half that found in Canada (30\%) - yet the gap between immigrants and natives is considerably larger in Denmark than in Canada (at 2.7 times the rate versus 1.5, respectively) (OECD, 2015).

\section{Conclusion}

This article has sought to contribute to existing scholarship in two key ways. First, we argued that much of the muddiness surrounding the meaning of 'universalism', both conceptually and as a welfare state characteristic, stems from the fact that it has traditionally been treated as a classical concept (e.g. Van Lancker and Van Mechelen, 2015). After highlighting the tensions inherent in the universalist/selectivist dichotomy, we suggest that universalism should instead be treated as a family-resemblance concept (e.g. Collier and Mahon, 1993): welfare states are universal in that they share some subset of key universalist traits that typify a number of cases well, but no single case perfectly. A comparison of two cases with very different incarnations of universalism - Canada and Denmark - allows us to draw out the underlying relationship among these family-resemblance attributes, which we argue centre around a self-sustaining logic of solidarity. Most importantly, this 
comparison leads us to consider potential tensions between community perks and community scope traits, in particular within a context of rising immigration.

Second, our comparison of Canada and Denmark was also motivated by a separate but related debate: for the mainstream welfare state literature, the fact that the tension between the existing community and newcomers is much clearer in the Danish than the Canadian case presents a paradox. From this perspective, universalism (as traditionally conceived) should mitigate popular concerns about fraud and benefit misuse by certain groups, presumably by making 'us' versus 'them' distinctions less pertinent (e.g. Rothstein, 1998). Yet it is in classically 'universalist' Denmark, rather than the more selectivist Canada, that welfare chauvinism (with its implicit shrinking of community scope) is most prominent.

This paradox is solved, however, if we recognise that universalism and selectivism are not in fact contrasting concepts, and that certain selectivist traits may even reinforce solidarity and its extension to migrants. While various factors are clearly important to the integration of migrants into the universalist community - including multiculturalism, the conception of the nation, and the economic selection of immigrants (see Bloemraad, 2006; Winter, 2007; Kymlicka, 2013) - we argue that the more selective nature of Canada's universalism also plays an important role. On the one hand, the comparatively meagre set of Canadian community perks mean that even complete reliance on state assistance would not entail nearly as expensive a 'threat' as in Denmark. On the other, selectivist traits also ensure that 'deserving' immigrants, doing their part to contribute to the economy, are rewarded with the same (albeit limited) community perks available to everyone else. This point is made clearest by considering the dominant Canadian focus on the economic importance of immigration (see Winter, 2015): immigrants who bring their skills into the labour market will gain the same access as other Canadians. Indeed, when concerns about misuse are raised, they are typically directed toward lower-skilled migrants - 'illegal immigrants' and asylum 
seekers (taken to include 'bogus refugees') - and their use of programmes with eligibility criteria that are less discriminating between deserving and undeserving groups.

But while in Canada these sorts of community scope debates have been relatively rare, the same cannot be said for Denmark. The continued prominence of the concept faellesskab (i.e., community) in Danish politics reflects how strong the one-nation image with strong social citizenship remains in political discourse (see Vad Jønsson and Petersen, 2013). Yet the arrival (1995), breakthrough (1998), and influence on government (2001) of the anti-immigrant Danish People's Party (DPP) has clearly broken any semblance of an inclusive consensus (see Green-Pedersen and Krogstrup, 2008). Indeed, the 2015 electoral campaign was entirely overshadowed by what the Danes call the 'foreigner issue', which includes labour migration, refugees, and asylum-seekers, with the main parties competing over who was toughest on immigration. After the election, the Venstre-led minority government (supported by the DPP, the second-largest party in parliament), took as one of its first acts the restriction of immigrant rights, so as to make Denmark less attractive for less 'desirable', resource-poor migrants (see Danish Government, 2015, 23). The stated policy goal was to rigorously restrict the influx of such people by limiting (among other things) social rights, because they are a burden on the core perks of the Danish welfare state (kernevelford): healthcare and education.

Clearly one important driving factor here is the makeup of Denmark's growing migrant population, with includes a higher proportion of low-skilled migrant groups and a dramatic increase in asylum seekers over recent years, including relative to Canada (OECD, 2017). It is thus much easier to present newcomers to Denmark as net beneficiaries of the welfare state, especially in light of their comparatively low labour-market participation rates (e.g. Nannestad, 2004). Together, these features help to spread the perception that immigrants fail to contribute to the proper functioning of the welfare state and fail to behave like good community members (i.e. 'true' Danes) (Favell, 2003, 
24; OECD, 2015). As a consequence, immigrants are seen to benefit from a set of generous community perks they do not deserve.

The end result has been relatively high levels of welfare chauvinism (e.g. Bay et al., 2013). In light of the Danish welfare state's long list of comparatively indiscriminate community perks, restricting community scope by cutting immigrant access to social programmes can be understood as a perverse approach to protecting universalism as traditionally defined; these restrictions are argued to increase the long-term feasibility of and support for a comprehensive and generous - yet more exclusive - system. This suggests a possible trade-off between indiscriminate community perks and inclusionary community scope: to the extent that indiscriminate universalism reinforces the (perceived and/or real) importance of community boundaries, it may pose a challenge to the solidarity-reinforcing logic of universalism and its contemporary statecraft potential.

In sum, we find that - despite the stark contrast between the Danish and Canadian welfare states universalism has in both cases been central to a self-reinforcing logic of solidarity, ultimately playing a key role for individual integration into the national community. The use of social programmes for statecraft, linking 'the people' via social rights, has a long history in both countries. Yet the forms of universalism in Canada and Denmark differ dramatically, highlighting the value of a 'family-resemblance' approach to conceptualising universalism. Rather than comparing welfare states according to the classical universalist-selectivist contrast, we suggest that they should be thought of as embodying various 'packages' of universalist traits. In particular, our comparison of Canada and Denmark draws out how (indiscriminate/selectivist) 'community perks' traits may interact with (inclusive/exclusive) 'community scope' ones, which in turn helps us understand how and why 'classically universalist' Denmark is facing threats to solidarity that are much more intense than those found in 'classically selectivist' Canada. 
We conclude by noting that the (institutionalist) focus of this study has been necessarily narrow. We have not delineated all of the traits that underlie universalism as a concept, we have only explored the implications of our approach to universalism vis-à-vis migrant inclusion and integration into the national community, and we have not weighed up the impact of universalist traits on migrant integration relative to the effect of other factors. All three of these paths are useful avenues for additional study, but the last is most relevant for our current purposes - the present study is incapable of teasing out the comparative importance of welfare state, cultural, and nationalistic features, nor can it explore how these features might interact in meaningful ways. Nevertheless, by highlighting the value of our approach to understanding universalism and the insights regarding migrant integration that it can be used to draw out, we believe that we have helped to demonstrate its relative advantage and its potential use going forward. In our view, future research building from this study will thus have an easier time unpacking universalism and its consequences. 


\section{References:}

Agius, C, 2017, Drawing the discourses of ontological security: Immigration and identity in the Danish and Swedish cartoon crises, Cooperation and Conflict 52, 1, 109-125

Anttonen, A, Häikiö, L, Stefánsson, K, Sipilä, J, 2012, Universalism and the challenge of diversity, in A Anttonen (ed), Welfare State, Universalism and Diversity, (pp. 1-15), Cheltenham, UK: Edward Elgar Publishing

Ariely, G, 2012, Do those who identify with their nation always dislike immigrants?: an examination of citizenship policy effects, Nationalism and Ethnic Politics 18, 2, 242-261

Banting, K, 1995, The welfare state as statecraft: territorial politics and Canadian social policy, in S Leibfried, P Pierson (eds.), European social policy: Between fragmentation and integration (pp. 269-300), Washington, DC: Brookings Institution

Banting, K, Soroka, S, 2012, Minority nationalism and immigrant integration in Canada, Nations and Nationalism 18, 1, 156-176

Bay, AH, Finseraas, H, Pedersen, AW, 2013, Welfare dualism in two Scandinavian welfare states: Public opinion and party politics, West European Politics 36, 1, 199-220

Béland, D, Blomqvist, P, Andersen, JG, Palme, J, Waddan, A, 2014, The Universal Decline of Universality? Social Policy Change in Canada, Denmark, Sweden and the UK, Social Policy $\&$ Administration 48, 7, 739-756

Béland, D, Lecours, A, 2006, Sub-state nationalism and the welfare state: Québec and Canadian federalism, Nations and Nationalism 12, 1, 77-96

Béland, D, Lecours, A, 2007, Federalism, nationalism and social policy decentralization in Canada and Belgium, Regional and Federal Studies 17, 4, 405-419

Bloemraad, I, 2006, Becoming a citizen: Incorporating immigrants and refugees in the United States and Canada: Univ of California Press 
Brodie, J, 2002a, Citizenship and solidarity: Reflections on the Canadian way, Citizenship studies 6, 4, 377-394

Brodie, J, 2002b, An Elusive Search for Community: Globalization and the Canadian National Identity, Rev. Const. Stud. 7, 155

Burgoon, B, 2014, Immigration, Integration, and Support for Redistribution in Europe, World Politics 66, 03, 365-405

Campbell, JL, Hall, JA, 2010, Defending the Gellnerian premise: Denmark in historical and comparative context, Nations and Nationalism 16, 1, 89-107

Canada, 1945, Dominion-Provincial Conference on Reconstruction: Proposals of the Government of Canada

Carey, G, Crammond, B, 2017, A glossary of policy frameworks: the many forms of 'universalism'and policy 'targeting', Journal of Epidemiology and Community Health, 71, $303-307$

CBC News, 2015, 'Old stock Canadians,' egg timer, creepy set top debate's odd moments, 17 September, http://www.cbc.ca/news/trending/canada-election-2015-globe-debate-weirdmoments-1.3233233

Christensen, J, 2004, Socialreformen 1933: Principiel reform eller administrativ omlægning, in N Ploug, I Henriksen, N Kærgård (eds.), Den Danske Velfcerdsstats Historie, Copenhagen, Denmark: Socialforskningsinstituttet

Christiansen, NF, Petersen, K, 2001, The dynamics of social solidarity: The Danish welfare state, 1900-2000, Scandinavian Journal of History 26, 3, 177-196

Collier, D, Mahon, JE, 1993, Conceptual “stretching” revisited: Adapting categories in comparative analysis, American Political Science Review 87, 4, 845-855 
Crepaz, MML, Damron, R, 2009, Constructing Tolerance: How the Welfare State Shapes Attitudes About Immigrants, Comparative Political Studies 42, 3, 437-463

Curry, B, 2014, Refugee advocates blast proposed changes to welfare in budget bill, The Globe and Mail, 28 October, https://www.theglobeandmail.com/news/politics/refugee-advocates-blastproposed-changes-to-welfare-in-budget-bill/article21359353/

Danish Government, 2015, Sammen for fremtiden, http://stm.dk/multimedia/Regeringsgrundlag_2016.pdf

Edling, N, Petersen, JH, Petersen, K, 2014, Social Policy Language in Denmark and Sweden, in D Béland, K Petersen (eds.), Analysing social policy concepts and language: comparative and transnational perspectives, Bristol, UK: Policy Press

Esping-Andersen, G, 1990, The three worlds of welfare capitalism, Cambridge, UK: Polity Press

Esping-Andersen, G, 1999, Social Foundations of Postindustrial Economies, New York, NY: Oxford University Press

Favell, A, 2003, Integration nations: the nation-state and research on immigrants in Western Europe, in M Bommes, E Morawska (eds.), International Migration Research, (pp. 13-42), Aldershot, UK: Ashgate

Ferrera, M, 2005, The Boundaries of Welfare: European Integration and the New Spatial Politics of Protection Oxford, UK: Oxford University Press

Ferrera, M, 2016, Resemblances that matter: Lessons from the comparison between Southern Europe and East Asia, Journal of European Social Policy 26, 4, 374-383

Finkel, A, 1993, Paradise Postponed: A Re-examination of the Green Book Proposals, Journal of the Canadian Historical Association 4, 1, 120-142

Freeman, GP, 2004, Immigrant incorporation in western democracies, International Migration Review 38, 3, 945-969 
Goertz, G, 2005, Social Science Concepts: A User's Guide, Princeton, NJ: Princeton University Press

Goul Andersen, J., 2007, Restricting Access to Social Protection for Immigrants in the Danish Welfare State, Benefits 15, 3, 257-69.

Goul Andersen, J, 2012, Universalisation and de-Universalisation of Unemployment Protection in Denmark and Sweden, in A Anttonen, L Haikio, K Stefánsson (eds.), Welfare state, universalism and diversity, Cheltenham, UK: Edward Elgar

Green-Pedersen, C, Krogstrup, J, 2008, Immigration as a Political Issue in Denmark and Sweden, European Journal of Political Research 47, 5, 610-634

Jacques, O, Noël, A, 2018, The Case for Welfare State Universalism, or the Lasting Relevance of the Paradox of Redistribution, Journal of European Social Policy 28, 1, 70-85

Jensen, C, Petersen, M, 2017, The Deservingness Heuristic and the Politics of Health Care, American Journal of Political Science 61, 1, 68-83

Jespersen, KJ, 2011, A History of Denmark, Houndmills, UK: Palgrave Macmillan

Johnston, R, Banting, K, Kymlicka, W, Soroka, S, 2010, National Identity and Support for the Welfare State, Canadian Journal of Political Science 43, 2, 349-377

Kevins, A, 2017, Expanding Welfare in an Age of Austerity: Increasing Protection in an Unprotected World, Amsterdam University Press, Amsterdam, NL

Koning, E, 2013, Selective Solidarity: The Politics of Immigrants' Social Rights in Western Welfare States, PhD thesis, Queen's University

Koning, EA, Banting, KG, 2013, Inequality below the Surface: Reviewing Immigrants' Access to and Utilization of Five Canadian Welfare Programs, Canadian Public Policy 39, 4, 581-601 
Koopmans, R, 2010, Trade-offs between equality and difference: Immigrant integration, multiculturalism and the welfare state in cross-national perspective, Journal of Ethnic and Migration Studies 36, 1, 1-26

Kvist, J, Greve, B, 2011, Has the Nordic welfare model been transformed?, Social Policy \& Administration 45, 2, 146-160

Kymlicka, W, 2013, Neoliberal multiculturalism?, in AH Peter, L Michèle (eds.), Social Resilience in the Neoliberal Era, Cambridge, UK: Cambridge University Press

Laenen, T, 2018, Do Institutions Matter? The Interplay between Income Benefit Design, Popular Perceptions, and the Social Legitimacy of Targeted Welfare, Journal of European Social Policy 28, 1, 4-17

Larsen, CA, 2008, The Institutional Logic of Welfare Attitudes: How Welfare Regimes Influence Public Support, Comparative Political Studies 41, 2, 145-168

Lieberman, RC, 2005, Shaping Race Policy: The United States in Comparative Perspective, Princeton, NJ: Princeton University Press

Lukes, S, 2005, Power: A Radical View, Hampshire: Palgrave Macmillan

Marshall, TH, 1950, Citizenship and Social Class, Cambridge, UK: Cambridge University Press

McEwen, N, 2005, The territorial politics of social policy development in multi-level states, Regional and Federal Studies 15, 4, 537-554

Nannestad, P, 2004, Immigration as a challenge to the Danish welfare state?, European Journal of Political Economy 20, 3, 755-767

Noël, A, 2018, Le Canada Est Parmi Les Derniers De Classe Au Chapitre Des Dépenses Sociales Publiques En Pourcentage Du PIB, in Options politiques: Institut de recherche en politiques publiques (IRPP), Montreal, Canada

OECD, 2015, Indicators of Immigrant Integration 2015: Settling In, Paris, France 
OECD, 2017, International Migration Outlook 2017, OECD Publishing, Paris

OECD, 2018a, Health Data, Paris, France

OECD, 2018b, Social Expenditure: Aggregated data, Paris, France

Østergård, U, 1992, Peasants and Danes: the Danish national identity and political culture, Comparative Studies in Society and History 34, 01, 3-27

Rothstein, B, 1998, Just Institutions Matter: The Moral and Political Logic of the Universal Welfare State, New York, NY: Cambridge University Press

Schumacher, G, van Kersbergen, K, 2016, Do mainstream parties adapt to the welfare chauvinism of populist parties?, Party Politics $22,3,300-12$.

Siltanen, J, 2002, Paradise paved? Reflections on the fate of social citizenship in Canada, Citizenship studies 6, 4, 395-414

Soroka, SN, Johnston, R, Kevins, A, Banting, K, Kymlicka, W, 2016, Migration and welfare state spending, European Political Science Review 8, 2, 174-93

Soroka, S, Wright, M, Johnston, R, Citrin, J, Banting, K, Kymlicka, W, 2017, Ethnoreligious Identity, Immigration, and Redistribution, Journal of Experimental Political Science 4, 3, $173-182$

Stefánsson, K, Anttonen, A, Häikiö, L, Stefánsson, K, 2012, What is in a word? Universalism, ideology, and practice, Welfare state, universalism, and diversity, Edward Elgar, Cheltenham, UK

Vad Jønsson, H, Petersen, K, 2013, From a "Social Problem" to a "Cultural Challenge" to the National Welfare State: Immigration and Integration Debates in Denmark 1970-2011, in AM Suszycki, IP Karolewski (eds.), Citizenship and Identity in the Welfare State, Baden Baden: Nomos 
Van Kersbergen, K, 2000, Political allegiance and European integration, European Journal of Political Research 37, 1, 1-17.

Van Kersbergen, K, Vis, B, 2013, Comparative Welfare State Politics, Cambridge University Press, Cambridge, UK

Van Lancker, W, Van Mechelen, N, 2015, Universalism under siege? Exploring the association between targeting, child benefits and child poverty across 26 countries, Social Science Research 50, 60-75

Van Oorschot, W, 2000, Who should get what, and why?: On deservingness criteria and the conditionality of solidarity among the public, Policy \& Politics $28,1,33-48$

Winter, E, 2007, Neither 'America' nor 'Québec': constructing the Canadian multicultural nation, Nations and Nationalism 13, 3, 481-503

Winter, E, 2015, Rethinking Multiculturalism After its "Retreat" Lessons From Canada, American Behavioral Scientist 59, 6, 637-657

Wright, M, 2011, Policy regimes and normative conceptions of nationalism in mass public opinion, Comparative Political Studies 44, 5, 598-624 